\title{
An Anglo-Saxon Great Hall Complex at Sutton Courtenay/Drayton, Oxfordshire: a royal centre of early Wessex?
}

\section{By Naomi Brennan and Helena Hamerow, with contributions by Lorraine Higbee and Lorraine Mepham}

\section{SUMMARY}

An archaeological evaluation at the site of an Anglo-Saxon 'great hall complex' at Sutton Courtenay/Drayton (NGR 448733, 193671), previously known primarily from aerial photographs and metal-detector finds, included the partial excavation of two large timber buildings. One of these proved to be the largest Anglo-Saxon 'great hall' yet identified and had been cut into a prehistoric mound or bank. The smaller building overlay an earlier sunken-featured building of probable sixth-century date. The geophysical survey and excavation provide significant new information regarding the site, which is probably that of an undocumented royal centre associated with the earliest rulers of the West Saxons.

\section{INTRODUCTION}

In June, 2009, an archaeological evaluation was undertaken by Channel 4's 'Time Team' at the site of Sutton Courtenay/Drayton (Illus. 1; NGR 448733, 193671). The existence here of a group of exceptionally large timber buildings of presumed AngloSaxon date, set amid a range of prehistoric monuments, was already known from aerial photographs (Benson and Miles 1974; Hawkes 1986, 88-89). Several episodes of archaeological investigation had already taken place to the east of the 
evaluation area. The earliest of these were conducted by E.T. Leeds in advance of gravel extraction during the 1920s and 1930s (Leeds 1923; Leeds 1927; Leeds 1947). His excavations uncovered thirty-three sunken-featured buildings (SFBs or Grubenhäuser) ranging in date from the fifth or early sixth century to the seventh, as well as traces of earth-fast timber buildings. The archaeological complex as a whole straddles the boundary between the parishes of Sutton Courtenay and Drayton, although the present evaluation was located within the parish of Drayton. Hereafter, for the sake of simplicity, the site is referred to as Sutton Courtenay, the name by which it has been most commonly known since Leeds' day.

Metal-detector finds reported to the Ashmolean Museum in the 1990s point to the existence of an early Anglo-Saxon cemetery just to the south of Leeds' excavations. The finds indicate that this had contained at least one and probably several richly furnished burials dating to the late sixth or early seventh century. Fourteen silver coins (sceattas) recovered by metal dectorists from the same field suggest that the cemetery was succeeded in the early eighth century by a market or meeting place. Mid Saxon commercial activity is also suggested by the presence of Ipswich Ware in the fill of one of six curvilinear ditched enclosures identified in a watching brief some $2 \mathrm{~km}$ to the NE of the great hall complex and less then $200 \mathrm{~m}$ south of the Thames (Mundin and McNicoll-Norbury 2009; the author is grateful to Professor John Blair for drawing this find to her attention). Ipswich Ware rarely occurs in the Upper Thames Valley and, when found west of London, appears to be associated with places of special status (Blinkhorn 2009). The site lies just to the east of Sutton Wick, a placename first recorded in the thirteenth century as 'Westwike' and originally interpreted as referring to a dairy farm (Gelling 1974, 406). In this instance, however, the 'wick' 
element seems more likely to indicate a place where commercial activity was carried out (Coates 1999, 86); by the time Ipswich Ware was reaching the Upper Thames Valley in the eighth century, Sutton (the suth-tun) and, by extension, Sutton Wick are likely to have been satellites of Abingdon Abbey. The field-name 'Wickfield' (OE wīc feld) is, furthermore, recorded in seventeenth-century documents, although the location of the Wickfield lay cannot now be established (Gelling 1974, 425).

The easternmost of the large timber buildings visible in aerial photographs lay to the east of Milton Road and was partly excavated in 2002 (Hamerow, Hayden and Hey 2008). Most of the great hall complex, however, lies to the west of Milton Road (Illus. 1). The 'Time Team' evaluation thus represented the first opportunity to carry out a direct investigation of the core of this important complex.

The 2009 evaluation consisted of a geophysical (resistance and magnetic) survey (GSB 2009) and four evaluation trenches. Several objectives were defined: first, to investigate the relationship between a presumed prehistoric ring ditch and the largest of the Anglo-Saxon buildings; second, to establish whether Anglo-Saxon occupation had existed in this part of the site prior to the construction of the great hall complex and whether the presence of SFBs in the field that contained the great halls, suggested by the aerial photographs, could be established; third, to obtain dating evidence for the construction and/or occupation of the complex; and finally, to obtain constructional detail relating to two of the large timber buildings. Given the extreme rarity of such high-status complexes in Britain, the best known of which is the Northumbrian royal vill of Yeavering (Hope-Taylor 1977), the opportunity to investigate the Sutton Courtenay great halls was exceptional. 
The Scheduled area (list entry 1004852) covers approximately 22ha, spanning both sides of Milton Road. The evaluation was located to the west of the road and focused on the northern part of the scheduled area. The surrounding land, which occupies the Second Gravel Terrace of the Thames, is generally level, at a height of approximately $58 \mathrm{~m}$ OD. The underlying geology is a mixture of gravels, sand and limestone. The field is currently under pasture and, unlike the field to the east of Milton Road that yielded the metal-detector finds, has not been ploughed for some years. All the trenches saw the removal of between $0.16 \mathrm{~m}$ and $0.24 \mathrm{~m}$ of overlying topsoil and between $0.13 \mathrm{~m}$ and $0.25 \mathrm{~m}$ of subsoil in order to expose the underlying archaeology. Although features were visible at the very base of the subsoil, further stripping proved necessary in order to expose and clarify their form. Where encountered, the natural geology was a sandy pea gravel.

The large buildings identified within the area of the evaluation all lie within a defined topographical plateau (Benson and Miles 1974). Five rectangular features or structures can be seen in the aerial photos forming a rough 'L' shape with the long axis aligned east to west. One of the structures appears to overlap another small structure. A number of smaller, sub-rectangular features, possibly SFBs, can also be seen. Five circular, presumed ring ditches are in the immediate area of the evaluation with at least another four lying to the west and southwest. This complex of buildings lies c. $600 \mathrm{~m}$ south of a substantial palaeochannel of the Thames, although it is not possible to establish without further work whether this would have been navigable in the early medieval period.

Several sites belonging to earlier periods have been identified within or near the site of the evaluation. Within the site itself lies the southern part of the Drayton Cursus. 
This Neolithic monument extends for over $1.5 \mathrm{~km}$ on a north-north-east - southsouth-west alignment. A number of ring ditches thought to be Bronze Age lie mostly in the vicinity of the South Cursus (Barclay et al. 2003, 8-9). During excavation of four $20.0 \times 10.0$ m trenches to the east of Milton Road in 2003, some Early Neolithic activity in the area was indicated, and an apparently isolated late Bronze Age burial was discovered (Hamerow et al. 2008, 122-68). To the south-east of this, geophysical survey carried out in 2001 identified a circular anomaly some $32.0 \mathrm{~m}$ in diameter, interpreted as a barrow ditch, while another circular anomaly within an oval enclosure was thought to be potentially Neolithic in date (Hamerow et al. 2008; Martin 2004). The mass of linear and discrete features in this eastern part of the site were found to be of early Iron Age and Roman date; while continuity between the Iron Age and Romano-British phases of activity could not be demonstrated, the fact that the Roman boundaries appear to respect the limits of the early Iron Age settlement is suggestive (Hamerow, Hayden and Hey, 2008, 111).

Several Romano-British sites are known in the vicinity, most notably Dropshort villa roughly half a kilometre to the east of the great hall complex (Illus. 1). Dropshort villa was originally excavated in 1966 and was recently the subject of another 'Time Team' evaluation (Wessex Archaeology forthcoming). Certain finds, such as painted plaster, window glass and tessellated floors from the original excavations, indicate that this was a complex of some pretension. Pottery from the recent evaluation suggests that activity at the site spans the whole of the Roman period but with an emphasis on the late 3rd and 4th centuries. A geophysical survey carried out in 2001 to the east of Milton Road identified a series of sub-rectangular enclosures. Excavation demonstrated that these had been laid out in the early Roman period (mid-first to early second centuries AD) and it seems likely that they were associated 
with the villa (Hamerow, Hayden and Hey 2008; Barclay et al. 2003, 23; Martin 2004). An east-west trackway also established in the first or second century and still visible in the Anglo-Saxon period runs through the southern part of the site. It has recently been recognised that this represents the continuation of a trackway that passes immediately south of another great hall complex -- known so far only from aerial photographs -- at Long Wittenham, c $5 \mathrm{~km}$ to the east. The trackway continues eastward towards Dorchester-on-Thames - a documented early royal centre and seat of the first bishop of the West Saxons -- and would originally have served to connect these three important early Anglo-Saxon centres (see below; Hamerow, Ferguson and Naylor 2013, 67).

A feature identified as a potential SFB by the 2001 geophysical survey proved on excavation to be a probable waterhole and a series of intercutting pits of AngloSaxon date (Hamerow, Hayden, Hey 2008, 154).

Of most relevance to the current excavation was the 2002 trench positioned over the feature identified as a probable Anglo-Saxon timber building, estimated from geophysical survey to have been c. $19 \mathrm{~m}$ in length, significantly larger than the average building of the fifth to seventh centuries. The easternmost end of the building was exposed and partly excavated, demonstrating that the building was 9.0 $m$ wide and had an entrance in the eastern gable end (Hamerow, Hayden and Hey $2008,160-66)$. Based on sections cut through the c $1 \mathrm{~m}$ wide by $1 \mathrm{~m}$ deep foundation trench, it was concluded that the walls had partly been constructed using double rows of planks set into the foundation trenches. Although the details of the building's construction were difficult to define with certainty, this type of construction is potentially comparable to that seen in some of the buildings excavated at another great hall complex at Cowdery's Down (Hants) (e.g. buildings C8 and C12; Millet and 
James 1983). A number of irregularities, particularly along the outer edge of the foundation trenches, may indicate the position of postholes. No datable material was recovered from the building, although the use of foundation trenches indicates a date of construction no earlier than the late sixth century (Hamerow 2012, 27). It appeared that the structure had been left to decay in situ.

\section{RESULTS OF THE EVALUATION}

\section{PRE-SAXON ACTIVITY}

It has been recognized for some time that some early Anglo-Saxon sites - burials but also some settlements, and particularly those of high status - were deliberately associated with earlier monuments (Williams 1997, Blair 1994, 32; Semple 2004; Crewe 2012). Establishing whether the Drayton cursus and presumed Bronze Age barrows were still visible in the early medieval period is therefore directly relevant to determining whether the siting of the great halls amongst these earlier monuments represents a deliberate juxtaposition, or is merely a coincidence. Despite several investigations, it remains unclear whether the cursus survived as an earthwork into the early medieval period (Barclay 2003). If it did, it appears to have had no discernible impact on the layout of the great hall complex. The site also contains, however, at least five ring ditches extending across the cursus, presumably part of a larger barrow cemetery that included three ring ditches of probable early Bronze Age date excavated by Leeds (Barclay 2003, 22-23). One of these circular features can clearly be seen in aerial photos to intersect with the largest of the rectangular buildings. Trench 1 was positioned to investigate this relationship and establish, if possible, whether the ring-ditch had been deliberately back-filled during the early 
medieval period, prior to the construction of the hall. Such backfilling has been demonstrated at the early Anglo-Saxon settlement of Radley, Barrow Hills (Oxon.) (Chambers and McAdam 2007 84).

Geophysical survey indicated that the circular ditch was some $13.0 \mathrm{~m}$ in diameter with a possible central feature. Excavation confirmed that the ditch was relatively substantial (at least $0.5 \mathrm{~m}$ deep) and discontinuous, with a narrow break on the western side. Questions remain as to its date and function. The depositional sequence within the terminal was shown to be a deep gravelly (primary) fill representing the collapse of the feature's sides during initial stabilisation after excavation (Illus 2 \&5). This was followed by a period of more gradual silting overlain by a gravel-rich fill located on the inner edge of the ditch. Its position and high gravel content suggest that this was the result of the erosion of an internal bank or mound. This was followed by another episode of gradual deposition of silt and topsoil-derived material. The small amount of pottery recovered from this feature was found in the upper ditch fill, and is therefore likely to relate to its abandonment and possible reuse rather than its construction. The three sherds were not diagnostic and could range from the Middle Bronze Age through to the Middle Iron Age. Assessment of mollusc samples taken from the ring ditch, indicate that a generally open landscape setting existed locally at the time.

The presence of a defined ditch terminal suggests that this feature may not be the remains of a barrow, although the cropmark evidence does suggest the existence of a central feature, potentially a burial; it was not possible to investigate this feature, however. The deposit seen on the eastern side of the ditch was derived from the erosion and stabilisation of either a bank or a mound. It is possible to conclude, on the basis of prehistoric pottery found in the upper ditch fill, that the circular ditch had 
been infilled long before the Anglo-Saxon building was constructed. It is nevertheless likely that the bank or mound remained visible, and would have had to have been at least partly levelled prior to the building's construction. A strikingly similar relationship has, at the time of writing, just been identified at Lyminge, where one of the long walls of a large, earth-fast timber building of later sixth- or seventh-century date has been shown to cut a prehistoric ring ditch (G. Thomas, Pers. Comm. 2014). One or more of the larger barrows are also likely to have been visible in the early medieval period.

Apart from a small number of sherds from a feature in Trench 4, little evidence of Iron Age or Romano-British activity was recovered, in contrast to what was found to the east of Milton Road (see above). A small copper alloy antoninianus of the late third century AD was found in the subsoil of Trench 2.

\section{THE ANGLO-SAXON PERIOD}

\section{Excavation of the Sunken-featured building}

Trench 3 was positioned in order to investigate the apparent intersection between one of the smaller timber buildings and a feature identified as a possible sunkenfeatured building. This confirmed the presence of a SFB (Feature 330) measuring $3.9 \mathrm{~m}$ long by $2.6 \mathrm{~m}$ wide, and $0.38 \mathrm{~m}$ deep, and cut by the rectangular building (Illus.

\section{$3,4 \& 5)$.}

The shape and size of the Sutton Courtenay SFB lie within the normal parameters for a structure of this type (Tipper 2004,64 ). While the pottery from this feature could 
not be closely dated, the entire assemblage of around 100 sherds (714g) from across all trenches is undecorated and all but two sherds were organic-tempered. This suggests a date no earlier than the mid sixth century for most of the assemblage (Hamerow, Hollevoet and Vince 1995). A single fragment of RomanoBritish greyware was found in the upper fill. An iron knife with a straight back and curved cutting edge dating from the mid 5th to the early 7th century, although recovered from the subsoil, was also thought to have come from this feature (Böhner's type B, Böhner 1958; Evison Type 2, Evison 1987, 115, text figure 22). A fragment of a composite, double-sided bone or antler comb recovered from the lower fill of the SFB derives from a common Saxon type and is not closely datable. Three postholes were identified within the SFB during excavation and irregularities in the shape of the feature in plan hint at the existence of at least three more.

In common with many SFBs, that uncovered in Trench 3 contained a bipartite fill. Both deposits ((303), (304)) consisted of a mid grey-brown sandy silt loam and represent periods of rapid deposition consistent with deliberate backfilling. A few SFBs found at other sites have produced evidence of cross-joins between pottery sherds found in the upper and lower fills, indicating that these deposits were unlikely to have been widely separate events (Tipper 2004, 106-7).

The relatively large quantity of animal bone found in the fill of the SFB is not unusual for such buildings. In this instance, however, there is reason to think that some of the faunal remains derived from one or more 'placed deposits', many of which appear to relate to termination rituals carried out when such structures went out of use (Hamerow 2006; Sofield 2012). Specifically, the presence of an articulated segment of cattle spine and ribs, the remains of at least four juvenile pigs - including suckling pigs -- (not articulated, though with largely complete bones), a dog skull and 
a complete horse mandible are suggestive of one or more such deposits, which are most often, though not always, found on or just above the base of the feature.

Although animal bone was recovered throughout both deposits, the articulated cattle bone certainly lay just above the base of the feature. Several examples of probable 'placed deposits' were also uncovered in Leeds' excavations (Hamerow et al. 2008, 185).

Apart from the possible 'placed deposit', much of the material found in SFB 330 is likely to be the result of tertiary deposition, i.e. midden material used to backfill the sunken area once the building went out of use. Since this pattern of deposition has been demonstrated across a number of sites, the deliberate backfilling of the SFB cannot be interpreted as the need to demolish or level this structure prior to the construction of the timber building. Indeed, the radiocarbon date derived from articulated animal bone found just above the base of the SFB (see below) indicates that SFB 330 had been backfilled by the middle of the sixth century, probably several decades before the construction of Building 329, part of the great hall complex. This does not of course preclude the possibility that other features revealed in the aerial photographs and geophysical survey represent further SFBs that were contemporary with the great hall complex. Indeed, SFBs excavated by Leeds produced seventhcentury pottery (Hamerow et al. 2008, 184).

The evaluation has thus established that this part of the site was in use prior to the construction of the great hall complex, and that SFBs were scattered across a wide area spanning both sides of Milton Road, stretching some 500m from N-S and covering more than 10 ha. 


\section{Excavation of the Timber buildings}

It was possible partially to excavate two of the rectangular timber buildings. Trenches 1 and 4 were positioned at the western and eastern ends of Building 500, the largest of the buildings, in order to investigate the following: its relationship with the circular ditched feature (see above; Illus. 6 \& 7); details of its construction and, specifically, whether a western entrance into the building existed; the eastern entrance clearly visible in the geophysical survey and two pit-like features potentially associated with it (entrances were sometimes the locus of architectural elaboration and 'placed deposits', especially in buildings of high status, and so are of particular interest; Hamerow 2012, 43). Trench 3 was positioned over the eastern end of one of the smaller buildings (329) lying in the western part of the evaluation area in the hope of elucidating its relationship with SFB 330, as described above. The analysis and interpretation of these structures is significantly constrained by the limited scale of the excavation, but certain observations can nevertheless be made.

The evaluation established that Building 500 measured $30.9 \mathrm{~m} \times 10.8 \mathrm{~m}$, making it the largest Anglo-Saxon timber building found to date in Britain, though it is closely followed in size by Building A4 from Yeavering (25.3m x 11.6), Building C12 at Cowdery's Down $(22.1 \mathrm{~m} \times 8.8 \mathrm{~m})$ and the great hall uncovered in 2012 at Lyminge, Kent (21m x 8.5) (Hope-Taylor 1977, fig. 61; Millett and James 1984, 215; Thomas and Knox 2012a; Thomas and Knox 2012b; Thomas 2013). Its foundation trenches were steep-sided with a flat base and, though significantly truncated, survived to a depth of c $1.0 \mathrm{~m}$, ranging from $0.7-0.9 \mathrm{~m}$ in width (Illus 8 \& 9). The fill consisted of alternating bands of sandy silt loams and sandy gravels. A short section of the foundation trench was excavated, revealing a posthole (119) for an upright timber cut into the base; this contained a mixed, secondary fill and no visible post-pipe. The 
posthole shows slumping from the overlying banded deposits, and the western edge of the posthole slopes in line with this slumping, suggesting the post had been extracted in this direction, perhaps as part of a deliberate dismantling of the building. A gap in the southwest corner of the building, at the junction of the western and southern foundation trenches, is likely to have been the result of these having been cut as separate features. This also appeared to have been the case with the building excavated to the east of Milton Road (Hamerow et al. 2007,160-1). Comparable evidence can be seen at Lyminge and a number of other, albeit somewhat later, Anglo-Saxon buildings, for example buildings S11 and S13 at Portchester (Hants), (Thomas and Knox 2012; Cunliffe 1976, figs. 20 and 22) and Timber Hall 1 at Gamlingay (Cambs) (Murray and McDonald 2006, fig. 29).

A series of eleven clearly defined, regularly spaced external postholes lay immediately outside the northern and eastern foundation trenches. A single posthole uncovered outside the southern trench suggests that these continued all the way around the building. One of these external postholes (117) revealed a postpipe with a clearly raking profile, indicating that it held a timber that was angled steeply inward towards the wall (Illus. 8 \& 9). At Cowdery's Down, such external raking timbers were present in several buildings (including the largest, C12) and were interpreted as countering the downward thrust of the roof onto the roofplate, which would otherwise tend to rotate off the wall (Millett and James 1983, 242-3). The evidence from Building 500 is consistent with such an interpretation.

An internal partition located approximately $2.8 \mathrm{~m}$ from the western end of the building was indicated by a series of at least five relatively shallow, oval postholes $(5,194$, 195). On analogy with Building C9 at Cowdery's Down, these could mark the position of a door leading from the compartment formed by the partition into the main part of 
the building (Millett and James 1984, 212-13). Such compartments are relatively rare and are associated with larger-than-average buildings; they could often be entered from both outside and inside the building (Hamerow 2012, 38). The compartment in Building 500, however, could only have been entered from inside. It was not possible to ascertain any further details of the interior of the building due to the limited extent of the excavation, though the geophysical survey suggests a possible partitioning of the north-east corner.

Excavation of the eastern end of Building 500 (Trench 4) revealed, as anticipated, a centrally positioned entrance some $1.8 \mathrm{~m}$ wide. Three possible flanking postholes $(412,414,416)$ were noted in plan, but no clear relationship between these and the foundation trench (which was not excavated) was established. Within the entranceway was an exceptionally large and deep postpit (403). Traces of a postpipe (405) were clearly visible in section, suggesting that a substantial timber post, which would have blocked off the entrance - perhaps marking the end of the building's use and, indeed, 'lifecycle' -- had decayed in situ (Illus. 10); charcoal flecks in the fill, though abundant, were insufficient to demonstrate burning of this substantial timber. The use of free-standing posts is paralleled at Yeavering, where, for example, one was inserted into the centre of the Western Ring-ditch complex (Hope-Taylor 1977, 108-112; fig. 63); none, however, was used to block off an entrance. No entrance was identified in the western end of the building, although it is likely that other entrances existed - for example, positioned centrally in the long walls. Indeed the geophysical survey suggests a break in the middle of the southern wall.

Little more could be discerned regarding the building's superstructure. Only three pieces of fired clay were found during the evaluation, all associated with Building 500; one burnt fragment retains a single wattle impression. While this evidence is 
too limited to enable any firm conclusion to be drawn, it is likely that, as at Cowdery's Down, wattle panelling was used between the vertical timbers (Millett and James 1983).

Chalk appears to have been associated almost exclusively with the upper backfill of the foundation trenches of Building 500 as well as the upper fills of its external raking postholes and internal partition. These fills were all characterised by abundant flecks of this material, which was soft and friable and appeared to have been modified in some way. Analysis of a sample revealed that, despite its friability, the chalk retained its natural laminations. Addition of water caused the sample to hydrate and gradually dissolve, suggesting that the chalk had been heated or burnt, but not slaked. This chalk, for which no local source would have been available (the nearest chalk geology lies to the south, in the Berkshire Downs and Chilterns), may have derived from the building itself. White lime-plaster was recovered from the foundation trenches of the great hall A2 at Yeavering, occurring there as 'diffuse, powdery concentrations...in the sockets of the wall timbers' (Hope-Taylor 1977, 53, 140). One of the great halls associated with the monastic site at Lyminge (Kent) has also produced fragments of daub with limewash (Thomas and Knox 2014) as has a large timber building at a high-status early medieval complex on the shore of Lake Tiss $\varnothing$ in Denmark (Bican 2010:152, fig. 5). Alternatively, the chalk could derive from some kind of floor surface.

A feature tentatively identified as a small pit just to the east of the entrance to Building 500 proved on excavation to be irregular, shallow and disturbed by animal burrows; this feature - which may be natural -- yielded most of the Roman material (nine sherds) recovered from the site. 
Building 329 measured c $7.0 \mathrm{~m} \times 11.5 \mathrm{~m}$, making it somewhat larger than the average Anglo-Saxon building (Illus $3 \& 4$ ). Its foundation trenches were squaresectioned and steep-sided, measuring approximately $0.75 \mathrm{~m}$ wide and $0.50 \mathrm{~m}$ deep; slightly shallower than the foundations of both Building 500 and the building to the east of Milton Road. No external raking posts were apparent. The base of the foundation trenches revealed no indication of postholes or slots, although only two small interventions were excavated and irregularities around the outer edge of the foundation trench, visible in plan, could indicate the presence of one or more posts set within the trench (cf the building to the east of Milton Road; Hamerow, Hayden and Hey 2008, 160, illus. 22). An entrance $1.20 \mathrm{~m}$ wide was located in the centre of the eastern gable wall. The fills of the foundation trenches contained alternating bands of sand and gravel, similar to, though less distinct than, those found in Building 500. Seven sherds of organic-tempered pottery were recovered from the foundation trenches. A narrow, linear north-south running feature (320) was found immediately next and perpendicular to the north-east corner of the building. This too was steep-sided, $0.62 \mathrm{~m}$ deep, had a posthole in the base and contained 12 small sherds of organic-tempered pottery. It is possible that it was contemporary with and related to the building, but this could not be established with certainty.

One objective of the evaluation was to establish whether fenced enclosures - which appear to be characteristic of great hall complexes and were presumably used to control access to certain spaces within them -- were associated with the timber buildings (Hamerow et al. 2008, 187; Hamerow 2012, 102). A series of closely spaced, staggered postholes (Illus. 5, 196) uncovered extending northward from the north-west corner of Building 500 almost certainly represents such an enclosure. The construction appears to be very similar to that used in the fenced enclosure or 
palisade associated with Phase C at Cowdery's Down, where the uprights were thought to 'have been used to clasp horizontal members, either planks or perhaps wattle hurdles' (Millett and James 1984, 209). It was not possible to trace the course of this enclosure beyond the edge of Trench 1, however. On analogy with Yeavering and Cowdery's Down, the fence is most likely either to have formed an enclosure around Building 500, around the smaller building visible as a crop-mark immediately to the west, or possibly a small enclosure linking the two.

\section{LATER ACTIVITY}

Little evidence of activity post-dating the great hall complex was found although an unstratified copper alloy strap end of probable ninth-century date was recovered. This was a double-riveted type, with a split end, convex-sided shafts and a zoomorphic terminal (Hinton 1996, fig. 16; Thomas 2003, class A). A small amount of medieval and post-medieval material was recovered from the overlying soil horizons.

\section{UNDATED FEATURES}

Trench 2 overlay a strong geophysical anomaly just to the west of the Neolithic cursus. This feature was also visible from the aerial photographs and was identified as a potential SFB. A sub-circular feature was identified, which proved to be a large, steep-sided pit, rather than an SFB. This pit was filled with a series of deposits including a deep primary fill, deliberately dumped material and two tertiary deposits. No artefacts were recovered from any of the pit fills, although a small, abraded, 
sherd of probable Late Iron Age or Romano-British date was recovered from one of the tertiary fills. The lack of artefacts and large diameter of this feature argue against it being a refuse pit; it may be a quarry pit or waterhole (cf Hamerow, Hayden and Hey 2008, 154-7).

\section{DISCUSSION}

\section{By Helena Hamerow}

The date of the great hall complex

The small amount of pottery found in the foundation trenches of both timber buildings was only datable broadly to the early to middle Saxon period; it may in fact pre-date the construction of the halls, occurring residually in the foundation trenches. The scarcity of finds recovered in direct association with the Sutton Courtenay buildings is, however, consistent with the generally 'clean' nature of the deposits found at Yeavering and Cowdery's Down (Hope Taylor 1977; Millett and James 1983, 249-50; Hamerow et al. 2008, 154). The lack of finds is clearly not in this case a reflection of the site's status, but instead is likely to reflect the erosion of occupation layers as well as early medieval patterns of deposition and waste disposal. Metal-detector finds of high-status metalwork probably deriving from burials and dating to the late sixth to early seventh centuries have been recovered just to the east of Milton Road, demonstrating that the community at Sutton Courtenay possessed considerable resources (Hamerow et al. 2008). This is indicated above all by the great hall complex itself, a testament to the material and social capital to which its builders had access: huge quantities of timber from managed woodland and substantial labour 
services. It is also worth noting the unusually high proportions of suckling pig, immature cattle and horse bones from the site (see Higbee, below), although it would be unwise to draw conclusions regarding status based solely on the animal bone assemblage from a single, bone-rich, SFB (Poole 2013, 322; Hamerow 2012, 159$62)$.

The lack of finds, exacerbated by the generally poor results from the environmental samples, meant that no independent dating evidence was recovered. Five articulated cattle thoracic vertebrae found just above the base of the SFB (330) and probably representing a 'placed deposit' (see above) did, however, provide the opportunity to obtain an AMS radiocarbon date for the abandonment of the structure. The sample (OxA-30138) dates to between cal. AD 423-547 at 95.4\% probability, indicating, as already noted, that several decade had passed between the backfilling of the SFB and the construction of Building 329 (Illus. 11). The post-pit (403) in the middle of the eastern entrance to Building 500 also produced a fragment of cattle mandible suitable for radiocarbon dating. This produced dates comparable to that for the SFB, i.e. between cal. AD 427 and cal. AD 573 (OxA-30139, OxA-30142). This indicates that the bone is almost certainly residual, as the building's use of foundation trenches and external raking posts indicates that it could not have been constructed before the late sixth or early seventh century.

The buildings and layout of the great hall complex

Three of the six large timber buildings visible as crop-marks across the site have now been investigated. All were sophisticated structures with an eastern gable 
entrance and substantial, square-cut foundation trenches, yet the buildings also display variability in terms of constructional techniques. Detailed comparison with the buildings excavated at Cowdery's Down and Yeavering is hampered not only by the limited extent of the evaluation at Sutton Courtenay, but also by the differing subsoils and degrees of preservation. While a small number of other 'great hall complexes' have been identified -- notably at Milfield, Northumb., Hatton Rock, Warwicks., and Atcham, Shropshire -- these are known exclusively or primarily from aerial photographs (Harding and Scull 1990; Rahtz 1970; St Joseph, 1975). It is nevertheless clear that Building 500, with its fenced enclosure, bears a marked resemblance to the great halls C12 at Cowdery's Down and A4 at Yeavering in its overall layout and use of external raking timbers. Yet, while the proportions of the building and method of construction are closely similar, they are not identical to those used at either of the two other sites. One is left with the impression of a shared mental template rather than a physical one.

Several new observations concerning the layout and development of the great hall complex can be made in light of the recent evaluation. It is now well established that high-status Anglo-Saxon sites of this period, both secular and religious, often displayed what Andrew Reynolds has called 'ritual symmetry' (although not the gridplanning and use of the short perch recently identified at other sites by John Blair; Blair 2013, 23; Reynolds 2003). This is most clearly apparent in the axially aligned buildings that are characteristic of such sites. This alignment has been plausibly interpreted - where entrances into buildings and enclosures are also aligned -- as a means of facilitating procession through the aligned structures (Blair 2005, 199-200; Reynolds 2003, fig. 2). Building 500 is axially aligned with a somewhat smaller building lying a short distance to the west (which, though clearly visible in aerial 
photographs, was not detected in the geophysical survey). This arrangement is strikingly similar to that of the great hall A4 at Yeavering with the smaller building A1, whose gable entrances were carefully aligned. Yet Building 500 appears not to have possessed a western entrance that would have provided access to the smaller building. Similarly, the axially aligned Buildings C14 and B/C15 at Cowdery's Down did not possess gable-end entrances (Millett and James 1984). One might also expect to find aligned entrances in the long walls of the three westernmost buildings, of which Building 329 is the northernmost. Neither the crop-marks nor the geophysical survey suggest the existence of such entrances, although in the absence of excavation this remains unproven. Procession was evidently not the sole reason for the alignment of some buildings. Perhaps such arrangements were also designed to impress by presenting 'an extended façade to the visitor', as has been argued for the late Saxon 'long range' (Gardiner 2011, 206).

The obvious similarity between Building 500 and Yeavering A4 has a plausible political context: the ruling dynasty of the Upper Thames region during the sixth and much of the seventh centuries, known as the Gewisse, appears to have sought an alliance with Northumbria around this time. This is reflected in King Oswald's sponsorship of the Gewissen King Cynegil's baptism and his subsequent marriage to Cynegil's daughter in the 630s, two highly charged ceremonies likely to have taken place at a royal centre near Dorchester (HE III, 7, Colgrave and Mynors 1979; ASC, s.a. 634-5, Whitelock 1961; Blair 1994, 38-41). The close similarities of the great halls at Yeavering, Sutton Courtenay and Lyminge, may thus reflect a shared 'court culture' and a desire on the part of the leaders of the Gewisse to emulate successful innovations originating in other kingdoms. The context for the link with northern 
Hampshire is less clear, as this region appears not to have come under West Saxon control until the late seventh century (Yorke 1995, 39-45).

Unlike the great hall complexes at Yeavering, Cowdery's Down and Lyminge, all of which underwent several phases of modification and rebuilding, the Sutton Courtenay/Drayton complex has as yet produced no conclusive evidence to indicate multi-phase development. The timber structure visible in aerial photographs (though not in the geophysical survey) that appears to overlap the northwest corner of Building 329 hints at more than one phase of construction, as does the fact that the building to the east of Milton Road is on a somewhat different alignment to the others. Yet the general coherence of the Sutton Courtenay/Drayton complex in terms of the orientation and layout of the buildings, combined with the lack of evidence so far for the rebuilding or remodelling of any of the halls so far investigated, suggests that it represents essentially a single phase of construction. It remains possible, of course, that a considerable period of time elapsed between the construction of the first timber building and the last.

It was suggested in 2008 that the three westernmost buildings were arranged not only in relation to each other but also to the largest of the prehistoric ring-ditches (Hamerow et al. 2008, 189). Indeed, a line drawn axially through these buildings roughly bisects this ring ditch (Illus. 1). It has been recognised for some time that an association between early Anglo-Saxon cemeteries and earlier monuments, while always important, became particularly pronounced during the seventh century (Williams 1997); an association with such monuments has also been argued to be a distinctive feature of high-status Anglo-Saxon settlements, both secular and religious (Blair 2005, 199-200; though see also Crewe 2012). The evidence from Trench 1 indicates that at least one, and therefore probably more, prehistoric monuments 
were visible when the great hall complex was constructed. These monuments, together with the complex itself, would have served to evoke powerful, if fictitious, rulers and provided a striking 'visual focus for a new dynasty that tied it to the land it claimed to rule' (Yorke 2008, 24).

\section{THE ANIMAL BONE}

By Lorraine Higbee

\section{Introduction}

The assemblage comprises 832 fragments (or $4.883 \mathrm{~kg}$ ) of animal bone, $95 \%$ of which is from two structures of presumed fifth- to seventh-century date. A relatively large amount of bone was recovered from SFB 330, with negligible amounts from hall 500 (Table 1).

SFB 330

Thirty-one percent of the 455 bone fragments recovered from SFB 330 are identifiable to species and skeletal element. Pig bones are common (90\% NISP), and these are from a minimum of four different animals aged between 2-7 months and 7-14 months (MWS B and C, after Hambleton 1999, 65). This kill-off pattern indicates that pigs were intensively managed for meat, in particular the tender meat from suckling pigs. It is not uncommon for pigs to be killed at a young age since they provide no secondary products, reach full body weight at a younger age than other livestock and have large litters. However, these animals were killed before they had reached full body weight, and from this we can assume that the economy of the site was able to absorb the loss. 
Cattle and sheep/goat bones are also relatively common in the assemblage from SFB 330. Many of the cattle bones are from new born calves and immature animals, and this suggests that cattle were primarily managed for secondary products. Most of the cattle bones are waste elements from primary butchery, and these include a horn core, and several mandibles and foot bones. Of note amongst the cattle bone assemblage are five thoracic vertebrae that were found in articulation towards the base of the feature. These bones represent a primary deposit associated with the abandonment and dismantling of the building and have been radiocarbon dated to the fifth or sixth century (see above). The sheep/goat bone assemblage, although relatively small, includes both cranial and post-cranial fragments, including two mandibles, one from a 1-2 year old and the other from a 2-3 year old animal (MWS D and E after Payne 1973). The sheep/goat assemblage includes one positively identified horn core from a goat.

Other identified species from the assemblage from SFB 330 include, in order of relative abundance, horse, domestic fowl, dog and goose. The horse bones include a mandible from a juvenile animal aged 31/2-41/2 years. Dog is represented by a near complete skull from a relatively young animal.

Hall 500

A total of 63 bone fragments were recovered from hall 500 but only 16 (25\%) are identifiable to species. The identified bones are mostly from cattle and sheep/goat, while less common species include pig, horse and domestic fowl. Several of the cattle bones are from calves and immature animals.

Discussion 
A large quantity of animal bone was recovered from SFB 330. The assemblage is dominated by pig bones, many of which are complete and from young animals. The general character of the assemblage suggests that a high proportion of the bones, but notably the pig bones and articulated cattle vertebrae, were deposited directly into the feature when it was abandoned, while others appear to have been redeposited from surface midden deposits given their fragmented nature and slightly weathered appearance (see Tipper 2004, 149-51).

\section{THE POTTERY}

By Lorraine Mepham

\section{Introduction}

The small assemblage includes later prehistoric, Romano-British, Saxon and postmedieval sherds. One sherd remains undated. The condition overall is fair to poor; there are one or two possible (Saxon) single-vessel sherd groups, but the very fragmentary condition prevents profile reconstruction, and in general sherds are small and abraded. Mean sherd weight overall is $6.8 \mathrm{~g}$.

The whole assemblage has been quantified by ware type (e.g. flint-tempered ware, Roman amphora, post-medieval redware) within each context, and the totals are presented in Table 2.

\section{Prehistoric}

Three sherds from Trench 1 (ditch terminus 104) are in flint-tempered fabrics, the flint inclusions relatively fine and well sorted. The sherds are not diagnostic, and on 
fabric grounds could fit within several different ceramic traditions, for example the fineware component of either the Middle Bronze Age Deverel-Rimbury tradition, or the post-Deverel-Rimbury tradition (Late Bronze Age/Early Iron Age). Alternatively, the sherds could be Middle Iron Age.

Four small, heavily abraded and undiagnostic body sherds from the upper fill of Trench 4 (possible pit 409) are in sandy fabrics. The fabric is not particularly distinctive and could be either of Iron Age or Saxon date.

\section{Late Iron Age/Romano-British}

Two small, grog-tempered sherds have been tentatively dated as Late Iron Age or Romano-British, although the possibility that they are Early Bronze Age (e.g. from the Collared Urn tradition) cannot be entirely ruled out (layer 205 over pit 211; feature 409).

Other sherds within this chronological group are clearly wheel-thrown, 'Romanised' wares and include coarse greywares and one sherd from a Spanish Dressel 20 amphora. Most of the Romano-British sherds came from Trench 4 (possible pit 409).

\section{Saxon}

The majority of the pottery assemblage comprises sherds dated as early/middle Saxon. All but two are in organic-tempered fabrics, with one sherd in a sandy variant with some organic inclusions, and a second in a sandy fabric with some calcareous inclusions. Sherd groups from two contexts $(303,304)$ within the SFB $(330)$ may represent single vessels, although only one group contained a rim sherd. Only one other diagnostic sherd was recovered - a vertically perforated, applied lug from a foundation trench (306). 
Nine sherds are post-medieval, and consist of coarse redwares and modern, refined whitewares. These sherds came from topsoil and subsoil contexts, and from one plough furrow (204).

\section{CONCLUSION}

\section{By Helena Hamerow}

As observed in 2008, the great hall complex at Sutton Courtenay lies in an area of exceptionally dense early Anglo-Saxon activity and is part of a nexus of seventhcentury sites of high status, notably a cemetery known as Milton II which lay c. $600 \mathrm{~m}$ to the south, and another great hall and cemetery complex at Long Wittenham, some $5 \mathrm{~km}$ to the east (Hamerow et al. 2008; Hamerow, Ferguson and Naylor 2013). Some $10 \mathrm{~km}$ to the east is the former Roman small town of Dorchester on Thames, which at the time the great hall complex was in use - had become the seat of the first bishop of the West Saxons (HE iii.7; Colgrave and Mynors 1979). The location of the Sutton Courtenay/Drayton complex within this concentration of sites, at the site of a probable portage and straddling what later became a parish boundary, has been commented upon elsewhere (Hamerow et al. 2008, 189-90). Both Sutton Courtenay and Long Wittenham were also sited at another major boundary, namely the Thames itself, which lay at the centre of a political struggle between the West Saxons and Mercians and which formed an increasingly contested frontier zone as the seventh century progressed (Blair 1994). A desire to assert and reinforce a shared identity is 
therefore likely to have been a factor in the political decision to construct the great hall complex on or near these boundaries (Cohen 1985,12).

The relationship between the great hall complexes at Sutton Courtenay and Long Wittenham is particularly intriguing: do they represent two, short-lived complexes, one succeeding the other, or were they contemporary? It has recently been recognised that a trackway established in the early Roman period and running $\mathrm{c}$ $150 \mathrm{~m}$ to the south of the great hall complex at Sutton Courtenay continues eastward, passing immediately south of the great hall complex at Long Wittenham. Its eastern course led ultimately to Dorchester on Thames. A visibility study has demonstrated, furthermore, that an individual walking along this trackway between Long Wittenham and Sutton Courtenay on a relatively clear day would always have been in sight of one of the two great hall complexes, which had relatively distinct viewsheds (Hamerow, Ferguson and Naylor 2013). Both observations lend weight to the idea that their periods of use overlapped.

This latest investigation thus confirms that Sutton Courtenay, like other early medieval 'places of power', was a composite site where a range of functions political, cultic, commercial, and craft - were carried out across a relatively wide area, with a great hall complex at its core (Hedeager 2001). Such complexes would, in the context of rapidly forming and expanding kingdoms, have provided impressive spaces in which to enact kingly power and negotiate royal relationships. A range of other high status complexes that emerged around the North Sea Zone during the fifth to seventh centuries display clear parallels in terms of their architecture, layout and association with (even manipulation of) ancient monumental landscapes places such as Gudme (DK), Uppåkra (SW), Tissø (DK) and Lejre (DK); like them, Sutton Courtenay would have acted as 'a ceremonial locus for the reinforcement of 
shared identities' (Yorke 2008, 24; Nielsen et al. 1994; Larsson 2002; Jørgensen 2003). At all such places, social cohesion appears to have been fostered by a range of communal activities centred on a great hall complex, including feasting, the giving (and probably manufacture) of precious gifts, and the burial of the dead. In short, great hall complexes such as the one investigated at Sutton Courtenay both expressed and helped shape the more hierarchical society that was emerging in Britain in the later sixth and seventh centuries.

\section{ACKNOWLEDGEMENTS}

This programme of post-excavation and assessment work was commissioned and funded by Videotext Communications Ltd. The authors would also like to thank Chris Welch (English Heritage) and Anni Byard (Finds Liaison Officer) for their advice and assistance. Finally thanks are extended to Lynda Ward for allowing access to the site for geophysical survey and archaeological evaluation.

The geophysical survey was undertaken by John Gater, Claire Stevenson and Emma Wood of GSB Prospection. The field survey was undertaken by Henry Chapman, University of Birmingham. The excavation strategy was devised by the late Mick Aston.

The excavations were undertaken by Phil Harding (Wessex Archaeology), Matt Williams, Ian Powlesland, Faye Simpson, Raksha Dave and Tracey Smith assisted by Jack Crennel, Phil Matthews, Dian King, Andy Hood, Charlotte Haines and Eoin Fitzsimons. The metal detector survey was carried out by Trevor Sprules and Kevin 
Benning. The on-site recording was co-ordinated by Naomi Hall (née Brennan), and on-site finds processing was carried out by Hannah Spieler, both of Wessex Archaeology. An on-line copy of the assessment report may be found in the ADS grey literature library http://archaeologydataservice.ac.uk/archives/view/greylit/ (doi: 10.5284/1023493) and also on the Wessex Archaeol website, http://www.wessexarch.co.uk/timeteam/reports.

All post-excavation analysis has been conducted by Wessex Archaeology. The illustrations were prepared by Rob Goller. The post-excavation project was managed on behalf of Wessex Archaeology by Lorraine Mepham.

The authors are also grateful to Professor John Blair and to the anonymous referees for their comments on a draft of the text.

\section{REFERENCES}

Primary Sources

HE. Bede's Ecclesiastical History of the English People, B. Colgrave, and R A B Mynors eds,1979, Oxford: Clarendon Press

Secondary Sources

Barclay, A., Lambrick, G., Moore, J. and Robinson, M. 2003. Lines in the Landscape, Cursus monuments in the Upper Thames Valley: excavations at the Drayton and Lechlade cursuses, Oxford: Thames Valley Landscapes Monogr., 15 
Benson, D and Miles, D. 1974. Cropmarks near the Sutton Courtenay Saxon Site, Antiquity, 48, 223-6

Bican, J. 2010. Bulbrogård, the first aristocratic complex at Tissø -- and a new approach to the aristocratic sites, Siedlungs- und Küstenforschung im südlichen Nordseegebiet 33, 147-54

Blair, J. 1994. Anglo-Saxon Oxfordshire, Stroud: Alan Sutton

Blair, J. 2005. The Church in Anglo-Saxon Society, Oxford: OUP

Blailr, J. 2013. Grid-planning in Anglo-Saxon settlements: the short perch and the four-perch module, Anglo-Saxon Studies in Archaeology and History 18, 18-61

Böhner, K. 1958. Die Fränkischen Altertümer des Trierer Landes, Germanische Denkmäler der Völkerwanderungszeit ser B, 2

Boyle, A., Dodd, A. Miles, D. And Mudd, A. 1995. Two Oxfordshire Anglo-Saxon Cemeteries: Berinsfield and Didcot, Oxford: Oxford Archaeological Unit

Chambers, R. And E. McAdam 2007. Excavations at Radley Barrow Hills, Radley, Oxfordshire, Vol. 2, Oxford Archaeology.

Cohen, A. 1985. The Symbolic Construction of Community, London: Ellis Horwood Ltd.

Crewe, V. 2012. Living with the Past: The Reuse of Prehistoci Mouments in AngloSaxon Settlements, BAR Brit. Ser. 573, Oxford: Brit. Archaeol. Rep. Brit. Ser.,573 
Gardiner, M. 2011. Late Saxon settlements, in H. Hamerow, D. Hinton and S. Crawford (eds), The Oxford Handbook of Anglo-Saxon Archaeology, 198-220, Oxford: OUP

GSB Prospection Ltd. 2009. Geophysical Survey Report: Sutton Courtenay, Oxfordshire, unpublished report

Hamerow, H. 2006. 'Special deposits' in Anglo-Saxon settlements, Medieval Archaeol., 50, 1-30

Hamerow, H. 2012. Rural Settlements and Society in Anglo-Saxon England, Oxford: OUP

Hamerow, H., Y. Hollevoet and A. Vince 1994. Migration Period settlements and 'Anglo-Saxon' pottery from Flanders. Medieval Archaeol. 38, 1-18.

Hamerow, H., Hayden, C. and Hey, G. 2007. Anglo-Saxon and Earlier Settlement near Drayton Road, Sutton Courtenay, Berkshire, Archaeol. J., 164, 109-6

Hamerow, H., Ferguson, C. and Naylor, J. 2013. The Origins of Wessex Pilot Project, Oxoniensia 78, 49-70

Hawkes, S. C. 1986. The Early Anglo-Saxon Period, in G. Briggs, J. Cook, T. Rowley (eds) The Archaeology of the Oxfrod Region, 64-108, Oxford: University of Oxford Department for External Studies

Hedeager, L. 2001. Asgard reconstructed? Gudme - a 'central place' in the North, in M. De Jong and F. Theuws (eds), Topographies of Power in the Early Middle Ages, 467- 507, Leiden: Brill 
Hinton, D. 1996. The Gold, Silver and Other Non-Ferrous Alloy Objects from Hamwic, Southampton City Museums, Southampton Finds Vol. 2

Hope-Taylor, B. 1977. Yeavering: An Anglo-British Centre of Early Northumbria, Dept Environment Archaeol. Rep 7, London: HMSO

Jørgensson, L. 2003. Manor and market at Lake Tissø in the sixth to eleventh centuries: The Danish 'productive' sites, in T. Pestell and K. Ulmschneider (eds), Markets in Early Medieval Europe: Trading and 'Productive' Sites, 650-850, 175-207, Macclesfield: Windgather Press

Larsson, L. 2002. Uppåkra: Research on a Central Place. Recent excavations and results, in B. Hårdh and L. Larsson (eds), Central Places in the Migration and the Merovingian Periods, 19-30, Lund: Dept. Of Archaeology and Ancient History Leeds, E. T. 1923. A Saxon Village near Sutton Courtenay, Berkshire, Archaeologia, 73, 147-92

Leeds, E. T. 1927. A Saxon Village near Sutton Courtenay, Berkshire (second report), Archaeologia, 76, 59-80

Leeds, E. T., 1947. A Saxon Village at Sutton Courtenay, Berkshire; third report, Archaeologia, 92, 79-93

Martin, L. 2004. Sutton Courtenay, Oxfordshire, Report on Geophysical Surveys, October 2001-March 2003, English Heritage: Centre for Archaeology Report 73/2004

Millett, M. and James, S. 1983. Excavations at Cowdery's Down, Basingstoke, Hampshire, Archaeol. J., 140, 151-279 
Mundin, A. And McNicoll-Norbury, J. 2009. 2 Abingdon Road, Sutton Courtenay, Oxfordshire. An Archaeological Watching Brief. Thames Valley Archaeological Services unpublished report, site code ARS 09/43

Murray, J. With McDonald, T. (2006). Excavations at Station Road, Gamlingay, Cambridgeshire, in Anglo-Saxon Studies in Archaeology and History 13, 173-330 Nielson, P.O. Randsborg, K. and Thrane, H. (eds), (1994). The Archaeology of Gudme and Lundeborg, Copenhagen: Akademisk Forlag

Poole, K. 2013. Horses for courses? Religious change and dietary shifts in AngloSaxon England, Oxford Journal of Archaeology 32.3, 319-34

Rahtz, P. 1970. A possible Saxon palace near Stratford-upon-Avon, Antiquity 44, $137-43$

Reynolds, A. 2003. Boundaries and settlements in late sixth to eleventh century England, in Anglo-Saxon Studies in Archaeology and History 12, 98-136 St Joseph, J.K.S. 1975, Air Reconaissance: Recent Results, 39, Antiquity 49, 293-5 Scull, C. and Harding, A. 1990. Two early medieval cemeteries at Milfield, Northumberland, Durham Archaeological Journal 6, 1-29

Semple, S. 2004. Locations of assembly in early Anglo-Saxon England, in A. Pantos and S. Semple (eds), Assembly Places in Medieval Europe, 135-54, Dublin: Four Courts Press

Sofield, C. 2012. Placed Deposits in Early and Middle Anglo-Saxon Rural Settlements, unpublished Dphil thesis, University of Oxford 
Thomas, G. 2003. Late Anglo-Saxon and Viking Strap-Ends 750-1100: Part 1, Finds Research Group AD700-1700 Datasheet 32

Thomas, G. 2013. 'Life before the minsters: the social dynamics of monastic foundation at Anglo-Saxon Lyminge, Kent', Antiquaries Journal 93, 109-45

Thomas, G. and Knox, A. 2012a. Lyminge excavations 2012. Interim Report, www.lymingearchaeology.org/publications

Thomas, G. and Knox, A. 2012b. A window on Christianisation: transformation at Anglo-Saxon Lyminge, Kent, England, Antiquity, 87 (334)

Thomas, G. and Knox, A. 2014. Lyminge excavations 2013. Interim Report, www.lymingearchaeology.org/publications

Tipper, J. 2004. The Grubenhaus in Anglo-Saxon England: an analysis and interpretation of the evidence from a most distinctive building type, Yedingham: Landscape Research Centre Archaeol. Monogr., Series 2: Vol. 1

Wessex Archaeology, 2010. Sutton Courtenay, Oxfordshire: Archaeological Excavation and Assessment of Results, unpublished report

Wessex Archaeology, forthcoming. Dropshort Roman Villa, Drayton, Oxfordshire: Archaeological Evaluation Report, unpublished report

Williams, H. 1997. Ancient Landscapes and the Dead: The reuse of Prehistoric and Roman Monuments as Early Anglo-Saxon Burial Sites, Medieval Archaeol., 41, 1-32 Yorke, B. 1990. Kings and Kingdoms of Early Anglo-Saxon England, London: Seaby 
Yorke, B. 2008. Anglo-Saxon origin legends, in J. Barrow and A. Wareham (eds), Myth, Rulership, Church and Charters: Essays in Honour of Nicholas Brooks, 15-29

Helena Hamerow, Professor of Early Medieval Archaeology, Institute of Archaeology, Oxford University, 34-6 Beaumont Street Oxford OX1 2PG

Email: helena.hamerow@arch.ox.ac.uk

Naomi Brennan, Heritage Consultant, Wessex Archaeology, Portway House, Old Sarum Park, Salisbury, Wilts SP4 6EB

Email: n.brennan@wessex.co.uk 